\begin{tabular}{|c|c|c|c|c|c|}
\hline$n$ & \begin{tabular}{|l} 
Manifestations \\
\end{tabular} & Haematological & Immunological & $\begin{array}{l}\text { Steroid at } \\
\text { lymphoma } \\
\text { diagnosis }^{2}\end{array}$ & $\begin{array}{l}\text { Immunosuppressant } \\
\text { at lymphoma } \\
\text { diagnosis }^{2}\end{array}$ \\
\hline 1 & $\begin{array}{l}\text { Rash, photosensitivity, } \\
\text { arthritis, pleuritis, } \\
\text { pericarditis }\end{array}$ & Leucopenia & $\begin{array}{l}\text { ANA, DNA, SS-A, } \\
\text { low C }\end{array}$ & Yes & Azathioprine (AZA) \\
\hline 2 & Arthritis & $\begin{array}{l}\text { Haemolytic } \\
\text { anaemia }\end{array}$ & ANA, Sm, SS-A & No & No \\
\hline 3 & $\begin{array}{l}\text { Rash, photosensitivity, } \\
\text { discoid, oral ulcers, } \\
\text { pericarditis }\end{array}$ & Lymphopenia & ANA, RNP & Yes & No \\
\hline 4 & $\begin{array}{l}\text { Rash, arthritis, epilepsia, } \\
\text { fever, adenopathies }\end{array}$ & Leucolymphopenia & $\begin{array}{l}\text { ANA, DNA, Sm, low } \\
\text { C }\end{array}$ & Yes & $\begin{array}{l}\text { Mycophenolate } \\
\text { (previous AZA) }\end{array}$ \\
\hline 5 & $\begin{array}{l}\text { Discoid, photosensitivity, } \\
\text { fever, hemophagocytic } \\
\text { syndrome }\end{array}$ & $\begin{array}{l}\text { Leucolymphopenia } \\
\text { thrombocytopenia }\end{array}$ & & Yes & $\begin{array}{l}\text { Previous } \\
\text { cyclophosphamide }\end{array}$ \\
\hline 6 & Oral ulcers & $\begin{array}{l}\text { Platelets }<20000 \text {, } \\
\text { haemolytic } \\
\text { anaemia }\end{array}$ & ANA, SS-A, low C & Yes & Rituximab \\
\hline 7 & Rash, photosensitivity & Leucolymphopenia & $\begin{array}{l}\text { ANA, SS-A, SS-B, low } \\
\text { C }\end{array}$ & Previous & No \\
\hline 8 & $\begin{array}{l}\text { Arthritis, epilepsia, CNS } \\
\text { vasculitis, stroke, } \\
\text { pleuritis, pericarditis }\end{array}$ & Thrombocytopenia & ANA & Yes & No \\
\hline 9 & $\begin{array}{l}\text { Arthritis, stroke, } \\
\text { glomerulonephritis }\end{array}$ & $\begin{array}{l}\text { Haemolytic } \\
\text { anaemia, } \\
\text { thrombocytopenia }\end{array}$ & $\begin{array}{l}\text { ANA, DNA, RNP, SS- } \\
\text { A, low C }\end{array}$ & Yes & Mycophenolate \\
\hline
\end{tabular}

Disclosure of Interests: None declared

DOI: 10.1136/annrheumdis-2019-eular.7580

\section{AB0537 CHRONIC DAMAGE CONTRIBUTION TO COGNITIVE IMPAIRMENT IN PRIMARY ANTIPHOSPHOLIPID SYNDROME}

Gabriela Medina ${ }^{1}$, Judith Rodríguez Torres ${ }^{2}$, Antonio Montiel Rivera ${ }^{3}$, Erik Cimé Aké $^{4}$, Miguel A. Saavedra ${ }^{5}$, María Pilar Cruz Domínguez ${ }^{6}$, Olga Lidia Vera Lastra ${ }^{2}$, Luis Javier Jara ${ }^{7}{ }^{1}$ Instituto Mexicano del Seguro Social, Clinical Research Unit, Mexico City, Mexico; ${ }^{2}$ Instituto Mexicano del Seguro Social, Internal Medicine, Mexico City, Mexico; ${ }^{3}$ La Salle University Nezahualcóyotl, Psychology, Nezahualcóyotl, Mexico; ${ }^{2}$ Instituto Mexicano del Seguro Social, Internal Medicine, Mexico City, Mexico; ${ }^{5}$ Instituto Mexicano del Seguro Social, Rheumatology Department, Mexico City, Mexico; ${ }^{6}$ Instituto Mexicano del Seguro Social, Research Division, Mexico City, Mexico; ${ }^{7}$ Instituto Mexicano del Seguro Social, Direction of Education and Research, Mexico City, Mexico

Background: There is a gamut of affections at neurological level in patients with primary APS (PAPS) including cognitive impairment (Cl). It presents in middle age population carrying a high risk of dementia. Objectives: To analyze the impact of chronic damage in $\mathrm{Cl}$ and its associated factors in patients with PAPS.

Methods: Cross-sectional study in patients with PAPS (Sidney criteria). Demographic, clinical data, comorbidities and treatment were investigated. For the diagnosis of $\mathrm{Cl}$, MoCA version 8.1 questionnaire was employed and HAD questionnaire for depression screening. Patients were divided into 2 groups: with and without $\mathrm{Cl}$. Chronic damage was measured with DIAPS, considering chronic damage as the damage established for over 6 months and with a score $\geq 1$. Descriptive statistics, and chi square test were used.

Results: Sixty PAPS patients were included, $76.7 \%$ were females. Clinical characteristics, associated risk factors and cognitive assessment by domain in both groups are shown in table 1.Only 1 patient presented depression and 3 had anxiety/depression by HAD test. Mild $\mathrm{Cl}$ was present in $61.7 \%$, moderate $\mathrm{Cl}$ in $6.7 \%$ and no $\mathrm{Cl}$ in $31.7 \%$. Median DIAPS score was 3 ,Interquartile Range 2-5.75. Thirty patients with $\mathrm{Cl}$ had a DIAPS score $\geq 3 \quad(p=007)$. Persistence of positivity for aCL was associated to $\mathrm{Cl}(\mathrm{p}=0.004)$

Conclusion: The high score of DIAPS and persistence of $\mathrm{aCL}$ were associated with $\mathrm{Cl}$ in PAPS. Chronic stress generated by accumulated chronic damage coupled with APS vasculopathy may contribute to cognitive deterioration. Prevention of chronic damage as well as a cognitive intervention are necessary in order to decrease $\mathrm{Cl}$.

\section{REFERENCES}

[1] Tektonidou MG, Varsou N, Kotoulas G, et al. Cognitive deficits in patients with antiphospholipid syndrome. Association with clinical, laboratory, and brain magnetic resonance imaging findings. Arch Intern Med 2006; 166: $2278-84$.

[2] Kozora E, Erkan D, Zhang L, et al. Cognitive dysfunction in antiphospholipid antibody (aPL)-negative systemic lupus erythematosus (SLE) versus aPL-positive non-SLE patients. Clin Exp Rheumatol 2014; 32: 34 - 40.

\begin{tabular}{|c|c|c|}
\hline & Without $\mathrm{Cl}(\mathrm{n}=19)$ & With $\mathrm{a}(n=41)$ \\
\hline \multicolumn{3}{|l|}{ Demographic factors } \\
\hline Age (years) & $48.1 \pm 14.7$ & $49.0 \pm 12.8$ \\
\hline Education (years) & $13.8 \pm 3.5$ & $12.0 \pm 4.3$ \\
\hline \multicolumn{3}{|l|}{ Disease characteristics } \\
\hline Age at diagnosis (years) & $36.0 \pm 12.5$ & $35.7 \pm 10.9$ \\
\hline Course (months) & $229.9 \pm 182.6$ & $222.8 \pm 144.8$ \\
\hline Stroke history (\%) & 15.8 & 41.0 \\
\hline$+\mathrm{aCL}(\$ s)^{\circ}$ & 73.7 & 92.0 \\
\hline B2GPI-1 (\$S) & 52.6 & 35.9 \\
\hline Triple aPL (96) & 23.1 & 42.1 \\
\hline \multicolumn{3}{|c|}{ Use of drugs a ss ociated to cognitive impairment } \\
\hline Benzodiazepines (56) & 10.5 & 20.5 \\
\hline \multicolumn{3}{|l|}{ Cognitive impairment by domain } \\
\hline Cognitive alteration (\$s) & 63.2 & 76.9 \\
\hline MoCA test score & $26.8 \pm 1.2$ & $22.1 \pm 2.8$ \\
\hline Executive-Visuospatial (Mdn, range) & $5,3-5$ & $4,2 \cdot 5$ \\
\hline Identification (Mdn, range) & $3,3 \cdot 3$ & $3,1-3$ \\
\hline Attention (Mdn, range) & $6,4-6$ & $5,1-6$ \\
\hline Language (Mdn, range) & $2,1 \cdot 3$ & $2,0-3$ \\
\hline Abstraction (Mdn, range) & $2,1.2$ & $2,0-2$ \\
\hline Deferred memory (Mdn, range) & $3,0 \cdot 5$ & $1,0-5$ \\
\hline Orientation (Mdn, range) & $6,5-6$ & $6,5-6$ \\
\hline Dementiarisk (96) & 5.3 & 46.2 \\
\hline
\end{tabular}

Disclosure of Interests: None declared DOI: 10.1136/annrheumdis-2019-eular.7968

\section{AB0538 INFLUENCE OF IMMUNOLOGICAL FEATURES, DISEASE ACTIVITY AND FATIGUE ON THE HEALTH-RELATED QUALITY OF LIFE IN PATIENTS WITH PRIMARY SJOGREN'S SYNDROME}

Rada Miskovic $^{1}$, Aleksandra Plavsic ${ }^{1}$, Maja Stojanovic ${ }^{1}$, Zikica Jovicic ${ }^{1}$, Aleksandra Peric Popadic ${ }^{1,2}$, Vesna Tomic Spiric ${ }^{1,2}$, Sanvila Raskovic ${ }^{1,2} .{ }^{1}$ Clinical Center of Serbia, Clinic of Allergy and Immunology, Belgrade, Serbia; ${ }^{2}$ Medical Faculty, University of Belgrade, Belgrade, Serbia

Background: Studies show that the health-related quality of life (HRQoL) is significantly reduced in patients with primary Sjogren's syndrome (pSS) However, potential predictors of HRQoL in these patients are not well known.

Objectives: To investigate potential influence of main immunological features, fatigue and disease activity on the HRQoL in patients with pSS. Methods: We studied 41 consecutive in- and outpatients with pSS diagnosed according to the AECG criteria in the Clinic of Allergy and Immunology. The SF-36 questionnaire has been used to assess HRQoL. The SF-36 values have been compared with the population based reference values. Fatigue was assessed using Fatigue Severity Scale (FSS). ESSDAl was used for the evaluation of systemic involvement and disease activity and ESSPRI for the evaluation of the patient-reported outcomes. Results: There were $38 / 41$ female patients. The mean age was 56.2 \pm 13.5 years and the mean disease duration was $3.9 \pm 5.8$ years. HRQoL was reduced in almost all SF-36 domains in the comparison to healthy population: physical functioning (PF) $(\mathrm{p}=0.0161)$; role physical (RP) $(p=0.0005)$; social functioning (SF) $(p=0.0234) ;$ role emotional (RE) $(p=0.0421)$. The mean value of FSS score was $4.6 \pm 2.2$, with $53.6 \%$ of patients having FSS score more than 4.8 (which is considered to be pathological). There were no significant differences in $\mathrm{HRQ}$ oL depending on the presence of ANA $(p=0.44)$, anti-SSA Abs $(p=0.0756)$, anti-SSB Abs $(p=0.218)$, cryoglobulins $(p=0.8)$, complement consumption $(p=0.122)$. Patients with elevated values of RF had significantly higher HRQoL $(p=0.00453)$. Serum $\lg G$ concentrations positively correlated with HRQoL (rho=0.488, $\mathrm{p}=0.00139$ ), and especially with the domains of SF (rho $=0.502, p=0.0005)$ and PF (rho=0.491, p=0.00129). We found a significant negative correlation between $\mathrm{HRQ}$ oL and FSS score (rho $=-0.794$, $\mathrm{p}<0.001)$. The mean ESSDAI score was $3.8(0-23)$, and $75.6 \%$ of patients had some level of disease activity according to ESSDAI. Patients with low disease activity had higher HRQoL compared to those with moderate disease activity in following SF-36 domains: physical composite score (PCS) ( $p=0.0148), P F(p=0.0328), R P(p=0.00697)$ and vitality (VT) $(p=0.05)$. The mean ESSPRI score value was $5.1 \pm 2.7$ (dryness scale 6.1, fatigue scale - 5.4, limb pain scale - 3.8). ESSPRI score negatively correlated with HRQoL (rho $=-0.763, p<0.001)$ in all SF-36 domains. Conclusion: Our study identified ESSDAI, ESSPRI and FFS scores, serum RF and $\operatorname{lgG}$ concentrations as potential predictors of HRQoL in patients with pSS 